Article

\title{
Fish Reproduction Is Disrupted upon Lifelong Exposure to Environmental PAHs Fractions Revealing Different Modes of Action
}

\author{
Caroline Vignet ${ }^{1}$, Thibaut Larcher ${ }^{2,3}$, Blandine Davail ${ }^{4}$, Lucette Joassard ${ }^{5}$, Karyn Le Menach ${ }^{4}$, \\ Tiphaine Guionnet ${ }^{5}$, Laura Lyphout ${ }^{1,5}$, Mireille Ledevin ${ }^{2,3}$, Manon Goubeau ${ }^{1}$, \\ Hélène Budzinski ${ }^{4}$, Marie-Laure Bégout ${ }^{5}$ and Xavier Cousin 1,6,7,* \\ 1 Ifremer, Ecotoxicology Laboratory, Place Gaby Coll, F-17137 L'Houmeau, France; \\ vignet.caroline@gmail.com (C.V.); llyphout@gmail.com (L.L.); manon.goubeau@gmail.com (M.G.) \\ 2 INRA UMR703, APEX, Oniris, F-44307 Nantes, France; thibaut.larcher@oniris-nantes.fr (T.L.); \\ mireille.ledevin@oniris-nantes.fr (M.L.) \\ 3 Oniris, École Nationale vétérinaire, Agro-Alimentaire et de L'alimentation Nantes-Atlantique, \\ LUNAM Université, F-44307 Nantes, France \\ 4 Department of Science and Technology, University of Bordeaux 1, EPOC, UMR CNRS 5805, \\ F-33405 Talence, France; b.davail@epoc.u-bordeaux1.fr (B.D.); k.lemenach@epoc.u-bordeaux1.fr (K.L.M.); \\ h.budzinski@epoc.u-bordeaux1.fr (H.B.) \\ 5 Ifremer, Fisheries Laboratory, Place Gaby Coll, F-17137 L’Houmeau, France; 1Joassar@ifremer.fr (L.J.); \\ tiphene9@hotmail.com (T.G.); mlbegout@ifremer.fr (M.-L.B.) \\ 6 INRA LPGP, Campus de Beaulieu, F-35042 Rennes, France \\ 7 Ifremer, Laboratoire Adaptation et Adaptabilité des Animaux et des Systèmes, UMR MARBEC, \\ Route de Maguelone, F-34250 Palavas les Flots, France \\ * Correspondence: xavier.cousin@ifremer.fr; Tel.: +33-5-4650-0621; Fax: +33-5-4650-0650
}

Academic Editor: Robert Tanguay

Received: 18 July 2016; Accepted: 19 October 2016; Published: 28 October 2016

\begin{abstract}
Polycyclic aromatic hydrocarbons (PAHs) constitute a large family of organic pollutants emitted in the environment as complex mixtures, the compositions of which depend on origin. Among a wide range of physiological defects, PAHs are suspected to be involved in disruption of reproduction. In an aquatic environment, the trophic route is an important source of chronic exposure to PAHs. Here, we performed trophic exposure of zebrafish to three fractions of different origin, one pyrolytic and two petrogenic. Produced diets contained PAHs at environmental concentrations. Reproductive traits were analyzed at individual, tissue and molecular levels. Reproductive success and cumulative eggs number were disrupted after exposure to all three fractions, albeit to various extents depending on the fraction and concentrations. Histological analyses revealed ovary maturation defects after exposure to all three fractions as well as degeneration after exposure to a pyrolytic fraction. In testis, hypoplasia was observed after exposure to petrogenic fractions. Genes expression analysis in gonads has allowed us to establish common pathways such as endocrine disruption or differentiation/maturation defects. Taken altogether, these results indicate that PAHs can indeed disrupt fish reproduction and that different fractions trigger different pathways resulting in different effects.
\end{abstract}

Keywords: polycyclic aromatic hydrocarbons; zebrafish; spawning success; fertilization; gonad differentiation; molecular mechanisms

\section{Introduction}

In ecology, recruitment is defined as the ability of one individual to contribute to the next generation. From birth, this includes a large number of abilities such as to develop, to grow, to meet 
congeners and to reproduce. Beyond intrinsic characteristics, genetically defined, many external factors can impede recruitment. Among them, xenobiotics could act on virtually all functions or important steps [1].

Among xenobiotics, polycyclic aromatic hydrocarbons (PAHs) form a diverse family of compounds containing at least two aromatic rings [2]. PAHs are increasingly emitted in the environment as a consequence of human activities $[3,4]$. There are two major types of environmental PAHs, petrogenic and pyrolytic, which enter the environment through different routes. Petrogenic PAHs are abundant in oils and enter the aquatic environment due to harbor activity or as a consequence of oil spills. Pyrolytic PAHs result from the incomplete combustion of organic matter, including fossil fuel; they enter aquatic environments through the deposition of atmospheric emissions directly on water or on the ground followed by soil runoff. Because PAHs are hydrophobic molecules, they are found to be associated with suspended particulate matter in water, such that they tend to accumulate in sediments; consequently, sediments constitute major sinks and can also act as secondary sources for aquatic systems contamination [5]. Monitoring networks have documented PAH concentrations of up to $50 \mu \mathrm{g} \cdot \mathrm{g}^{-1}$ dry weight (dw) in sediment from various affected aquatic ecosystems although the concentrations in highly contaminated areas are more commonly in the $10 \mu \mathrm{g} \cdot \mathrm{g}^{-1}$ range [6-11].

Thanks to its biological characteristics, including a short life cycle, the zebrafish makes a particularly good case study for performing longitudinal studies along the life cycle. This applies in the case of reproduction for which it is possible in some months to monitor the gonads' development and maturation, endocrine regulation and reproductive effort. In addition, the large numbers of tools developed to study zebrafish physiology allows for a refined analysis [12,13].

Reproduction is a key function to any species survival, but, at the same time, it is the target of some xenobiotics. Reproduction disruption may be the results of direct insults such as reproduction hormones modification in the case of endocrine disruptor compounds or may be the indirect consequence of general physiological degradation including growth or behavioral defects [14]. Additional complexity is due to the fact that reproduction is the ultimate step in a long-term process, from germ-cells' migration in embryos to gametes' maturation in reproducing adults, and that all these steps can be disrupted throughout life and eventually result in reproduction failure. Complexity is also due to the fact that, in the environment, xenobiotics are present as complex mixtures of compounds which, taken separately, can have pro- or anti-estrogenic properties [15]. PAHs have been shown to interfere with reproduction in fish and other animals, including invertebrates [16-25]. From a mechanistic point of view, many elements remain unclear; however, PAHs have been shown to produce endocrine disruption in fish, which has been revealed by disruption of circulating steroid hormones level in males and females [16,26-30].

In previous articles we have reported physiological disruptions observed in zebrafish after long-term diet exposure to environmentally relevant mixtures of polycyclic aromatic hydrocarbons (PAHs) and demonstrated disruption of growth, behavior and survival along with an increase in tumorigenesis [31-33]. In order to evaluate the reprotoxicity of environmental PAHs mixtures, zebrafish were exposed through diet from the first meal (5-days post fertilization (dpf)) and for the 9 following months, i.e., from larvae to reproducing adults. Three complex fractions of PAHs, representative of environmental situations, were used to spike the food: a pyrolitic (PY) fraction from sediment sampled in the Seine Estuary; and two petrogenic fractions, one from a heavy oil "Erika" (HO) and one from a light crude oil "Arabian light" (LO). We analyzed the consequences of this exposure on reproduction evaluated at functional, organ and molecular levels.

\section{Material and Methods}

\subsection{PAH-Contaminated Diet Preparation}

Three aromatic fractions were used for exposures: (i) A pyrolytic fraction (PY) extracted from sediments collected in a polluted site of the Seine Estuary (Oissel, France) and (ii) two petrogenic 
fractions obtained from Erika fuel (heavy oil; $\mathrm{HO}$ ) and Arabian Light crude oil (LO). PAHs extractions were performed as previously described [7]. Zebrafish TU strain (ZFIN ID: 76 ZDB-GENO-990623-3) was used and larvae were exposed from their first meal (at $5 \mathrm{dpf}$ ) onward using spiked food pellets [33]. Three concentrations, $0.3 \mathrm{X}, 1 \mathrm{X}$ and $3 \mathrm{X}$ were used with the $1 \mathrm{X}$ concentration corresponding to the 16 PAHs used as indicators by the US Environmental Protection Agency (US-EPA) at $5 \mu \mathrm{g} \cdot \mathrm{g}^{-1} \mathrm{dw}$ food, representative of the concentrations found in mollusks in the Seine Estuary. Although it does not give an accurate representation of the fractions' compositions, this subset of PAHs has been used for comparison with concentrations found in the environment (see in Table S1 a detailed description of actual fractions compositions). Diets are named after the origin of the fraction and its concentration: the 1X pyrolytic fraction diet will be named PY-1X. For each exposure, a fourth control treatment was included corresponding to the plain food treated as spiked-food with dichloromethane which was used as carrier solvent for PAHs spiking. Because the fraction extracted from the original sample is a mixture of PAHs, the term mixture will also be used more or less synonymously with fraction.

\subsection{Reproduction Monitoring}

Fish were reared in triplicates as batches of 25-30 individuals in $10 \mathrm{~L}$ tanks (see [33] for further details). Onset and spawning effort were determined by placing two spawning boxes (AquaSchwartz, Göttingen, Germany) at 17:00 on the bottom of each 10 L tank from 4 to 6 months post fertilization (mpf) in PY fish, from 4 to $7 \mathrm{mpf}$ in $\mathrm{HO}$ and from 5 to 9 in LO fish. In total, 19 to 87 spawning assays (solicitation) were performed depending on fraction and concentration (Table 1). Further monitoring of reproduction effort was performed with cross-pairing for $\mathrm{LO}$ and $\mathrm{HO}$ (without $\mathrm{HO}-3 \mathrm{X}$ ) using one exposed fish and one control fish pairwise mated overnight in a spawning box (AquaSchwartz, Germany) outside of the tank. In both cases (group and pairwise mating), spawning occurs the following morning progressively after a few minutes of light illumination. One hour later, eggs were collected, cleaned, sorted (into fertilized or none fertilized), and counted. The monitoring allowed us to assess spawning success (ratio of number of spawns obtained/number of assays), egg production (cumulative number of fertilized egg over observation time further normalized by the number of assays and the number of females in the tank) and spawn fertilization rate.

Table 1. Summary of group spawning monitoring.

\begin{tabular}{|c|c|c|c|c|c|c|c|c|c|c|c|c|}
\hline \multirow{2}{*}{ Figures } & \multicolumn{4}{|c|}{$P^{1}{ }^{1}$} & \multicolumn{4}{|c|}{$\mathrm{HO}^{2}$} & \multicolumn{4}{|c|}{$\mathrm{LO}^{3}$} \\
\hline & Control & $0.3 X$ & $1 X$ & $3 X$ & Control & $0.3 X$ & $1 X$ & $3 X$ & Control & $0.3 X$ & $1 X$ & $3 X$ \\
\hline Males & 19 & 31 & 36 & 43 & 46 & 39 & 47 & ND & 31 & 55 & 25 & 27 \\
\hline Females & 63 & 39 & 44 & 38 & 25 & 30 & 24 & ND & 37 & 29 & 37 & 25 \\
\hline Assays & 87 & 87 & 87 & 87 & 37 & 37 & 37 & 19 & 53 & 53 & 53 & 53 \\
\hline Spawns & 60 & 43 & 35 & 1 & 19 & 17 & 0 & 0 & 41 & 29 & 25 & 0 \\
\hline Eggs (total) & 6880 & 2921 & 4836 & 48 & 1065 & 582 & 0 & 0 & 6254 & 2498 & 1307 & 0 \\
\hline Eggs (fert.) & 5144 & 1927 & 3673 & 37 & 476 & 582 & 0 & 0 & 4894 & 1656 & 670 & 0 \\
\hline Fert. rate $(\%)$ & 74.8 & 66.0 & 76.0 & 77.1 & 88.1 & 81.8 & - & - & 78.3 & 66.3 & 51.3 & - \\
\hline
\end{tabular}

ND, not determined because of the small size of those fish. Spawns row indicates the number of successful spawns. Numbers in bold indicate success rates significantly different from Control group $(p<0.05) ;{ }^{1} \mathrm{PY}$, pyrolytic; ${ }^{2} \mathrm{HO}$, heavy oil; ${ }^{3} \mathrm{LO}$, Light crude oil.

\subsection{Histological Analysis}

Fish were sampled at $9 \mathrm{mpf}$ for all diets except for $\mathrm{HO}$ which were sampled at $7 \mathrm{mpf}$ because of high mortality in HO-3X condition. Control fish were systematically sampled in parallel. Fish were euthanized with a lethal dose of benzocaine $\left(250 \mu \mathrm{g} \cdot \mathrm{L}^{-1}\right.$ of a $10 \%$ solution in $100 \%$ ethanol; Sigma-Aldrich, Lyon, France) and fixed in $4 \%$ buffered formalin after ventral incision of the abdomen for larger individuals [34]. After $24 \mathrm{~h}$ of fixation, fins, most scales and the caudal peduncle were carefully removed and samples were dehydrated in graded ethanol solutions and embedded in paraffin. Step sectioning was performed as already published [35]. Serial sagittal step sections were cut from the left side of the fish. Four step sections from each adult fish were mounted on glass slides, 
one from the eye anterior chamber level, one from the eye posterior chamber level, one just medial to the eye, and one at the midline. Sections were routinely stained with haematoxylin-eosin-saffron (HES). A first histological analysis was performed to qualify structure and morphology on the gonads and also to identify lesions. The second step consisted of follicle staging (functional characterization). All oocytes present on mid-level section and on sections medial to the eye were counted along with identification of their morphological stage (F1 to F4) using middle magnification [36]. Individual frequencies of each type of follicles were calculated using ratio to the total ovarian area.

\section{4. qPCR Analysis}

Ovaries and testis were sampled on 9mpf animals from each fraction and concentration except HO-3X ( $N=5$ per case) euthanized as described above and immediately frozen in liquid nitrogen and stored at $-80^{\circ} \mathrm{C}$ until used. Total RNAs were extracted using Trizol Reagent (Invitrogen, Carlsbad, CA, USA) following the manufacturer's instructions. Total RNA concentration was quantified by spectrophotometry at $260 \mathrm{~nm}$. Furthermore, purity of RNAs was verified by measuring the A260/A230 $\mathrm{nm}$ and A260/A280 $\mathrm{nm}$ ratios. To remove the possibility of genomic DNA contamination, RNA sample was digested by RNase-free DNase I (Promega, Madison, WI, USA) and then purified. First-strand cDNA was synthetized from a total of $1 \mu \mathrm{g}$ RNA using reaction mix including $500 \mathrm{ng}$ of oligo(dT)15, $250 \mathrm{ng}$ of random hexamerprimers (Promega, Madison, WI, USA) using M-MLV Reverse Transcriptase (Promega, Madison, WI, USA) following manufacturer's instructions. Reaction was incubated for $1 \mathrm{~h}$ at $42{ }^{\circ} \mathrm{C}$ and inactivated by heating for $15 \mathrm{~min}$ at $70{ }^{\circ} \mathrm{C}$ and cDNA stored at $-20{ }^{\circ} \mathrm{C}$ until a real-time PCR analysis. PCR primers were designed with Primer 3 software. Real-time PCR reactions were performed using Fast SYBR Green Master Mix 5X (ThermoFisher, Illkirch, France) and in a StepOnePlus instrument (ThermoFisher, Illkirch, France) following the manufacturer's instructions. Gene's expressionwere quantified from the threshold cycle (CT) number and normalized to four housekeeping genes (eef1, Bactin, g6pd and gapdh). Gene expressions were analyzed in females (esr1, esr2a, esr2b, cyp19a1a) and males (amh, spag8, cyp17a1, hsd11b3) using REST-2009 software (Qiagen, Dusseldorf ,Germany).

\subsection{Statistical Analysis}

Within each fraction (PY, LO, HO), fertilization rate frequencies were calculated per classes (20\% wide) and Chi2 analysis performed to compare eggs fertilization rate as well as spawning success between concentrations using Prism 6.0 (Graphpad, La Jolla, CA, USA ).

Comparing fertilization rates in cross-pairings was performed using non-parametric test, Kruskal-Wallis, whereas GLMs were calculated to compare egg production within each fraction (PY, HO or LO) with concentration as fixed factors (Control, 0.3X, 1X and 3X). For PY ovary morphology, surface of degenerating areas expressed as percentage of total ovarian surface were compared between concentrations (Control, 0.3X, 1X and 3X) using ANOVA. For ovary quality evaluation within each fraction, concentration and follicles stages (F1 to F4) were used as a fixed factor and fish as random factor. Interaction between concentrations and stages was also analyzed. Post hoc tests were performed with Newman-Keuls in all cases. These statistical analyses were performed with Statistica 9.0 (Statsoft, Tulsa, OK, USA) software.

All statistical analyses were carried out at a 95\% level of significance and only the fixed factor and the interaction between them are presented in the text. The results reported in text and all figures are means \pm SEM.

\section{Results}

This work is part of a larger program that included analysis of modification of several physiological variables following exposure to the same diets. Chemical analysis of fractions, diets and metabolites have been presented previously [33]. Briefly, PY fraction was characterized by a high proportion of heavy PAHs $(82 \%)$ and almost no methylated derivatives $(<5 \%)$. HO fraction contained 
moderate levels of heavy PAHs (31\%) and methylated derivatives (45\%). LO fraction contained a very low level of heavy PAHs (6\%) and a high level of methylated ones (59\%). As mentioned above, proportions of light, heavy and methylated PAHs differ notably between fractions and spiked diets. Total PAHs concentrations based on 22 parents HAPs (including the 16 EPA PAHs) and 8 methylated PAHs are presented in detail in Table S1. Briefly, for PY, HO and LO respectively PAHs parents concentrations in $1 \mathrm{X}$ diets were $5.5 \pm 1.4,2.6 \pm 0.2$ and $2.7 \pm 0.2 \mu \mathrm{g} \cdot \mathrm{g}^{-1} \mathrm{dw}$ and $0.3 \pm 0.1,2.1 \pm 0.2$ and $4.0 \pm 0.3 \mu \mathrm{g} \cdot \mathrm{g}^{-1} \mathrm{dw}$ for methylnaphthalenes and methylphenanthrenes. This resulted in a similar total concentration of quantified PAHs (included methylated) in the three $1 \mathrm{X}$ diets: $5.8 \pm 1.4,4.7 \pm 0.4$ and $6.7 \pm 0.3 \mu \mathrm{g} \cdot \mathrm{g}^{-1} \mathrm{dw}$ for PY, HO and LO respectively. Since PAHs is a family of hundreds of compounds, it is not possible to quantify all individual PAHs and therefore we acknowledge that the above concentrations only partially describe the fractions used. Quantification of hydroxylated metabolites in dietary exposed $15 \mathrm{dpf}$-larvae confirmed an effective exposure of fish, and results were consistent with diet composition [33].

\subsection{Reproduction Monitoring}

Experimental groups showed varied sex-ratio with females to males $(\mathrm{F} / \mathrm{M})$ ratio ranging from 3.32 (PY Control) to 0.51 (HO-1X) while the overall mean ratio was 1.15 . When considering only Control conditions, HO-Control had a F/M ratio of 0.54 to PY-Control (F/M = 3.32) or LO-Control $(\mathrm{F} / \mathrm{M}=1.19)$. The varying sex ratio arose from the initial creation of the replicate at embryonic stage and the fact that reared replicate composition was not changed over time.

In a first step, group spawns were monitored directly in the rearing tanks starting at $4 \mathrm{mpf}$ for $\mathrm{PY}$ and HO fish and at $5 \mathrm{mpf}$ for LO fish. Results are summarized in Table 1. A significant number of spawns were obtained for all diets but $3 X$ concentration for all three fractions with only one spawn was obtained for PY-3X over 87 assays and none for HO-3X and LO-3X. The spawning success rate was significantly reduced after exposure to all three PAHs fractions (Chi2; $p<0.001)$. In more detail, this rate was reduced for all fractions and all concentrations compared to their respective control $(p<0.05)$ except for HO-0.3X $(p=0.81)$.

The cumulative number of fertilized eggs was monitored over time (Figure $1 \mathrm{~A}-\mathrm{C}$ ).
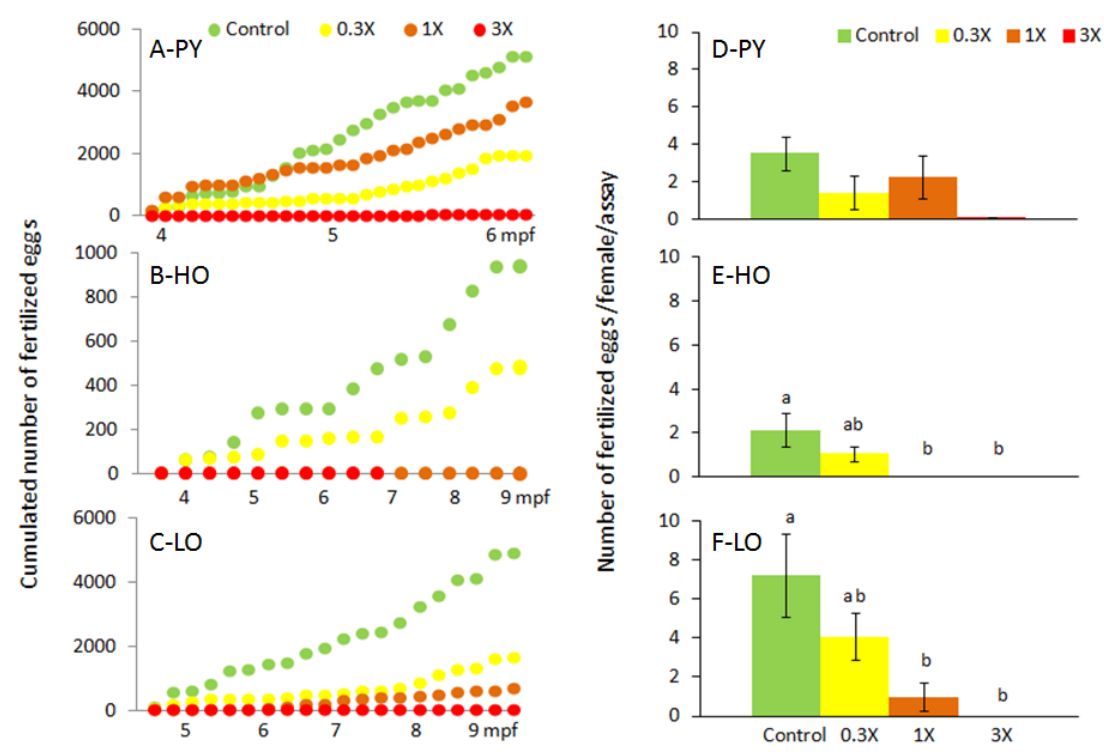

Figure 1. Monitoring of group-spawning. Cumulated number of fertilized eggs over-time (A-C) and number of fertilized eggs normalized to the number of spawning assays and the number of females in each tank (D-F) are presented for fish exposed through diet to PY (A,D), HO (B,E) and LO (C,F). In $(\mathbf{D}-\mathbf{F})$ mean \pm SEM. Different letters indicate significant difference $(p<0.05)$. Note that in $(\mathbf{A}-\mathbf{C})$, $x$ - and $y$-axes scales are different between conditions. 
The number of fertilized eggs spawned per female and assay was significantly reduced for fish exposed to petrogenic diets for $1 \mathrm{X}$ and $3 \mathrm{X}$ concentrations (Figure $1 \mathrm{D}-\mathrm{F}$ ). The $0.3 \mathrm{X}$ was intermediate. In the case of PY-3X, a trend was only obtained $(p=0.078)$ using the GLM analysis despite the fact that only one spawn was obtained with a hundred-fold reduction of the number of fertilized eggs per female per spawn.

Spawns mean fertilization rates ranged from $66.0 \%$ to $77.1 \%$ for PY fraction, from 81.8 to 88.1 for $\mathrm{HO}$ fraction and from 51.3 to 78.3 for $\mathrm{LO}$ fraction with a trend to follow a dose-effect decrease for this latter fraction. When classified according to their fertilization rates in $20 \%$ wide classes (Figure 2), this trend was confirmed (overall Chi2 $=18.48 ; p=0.02$ ). LO- $0.3 \mathrm{X}$ spawns tended to have a lower quality compared to Control (Chi2 $=7.17 ; p=0.13$ ) while LO-1X spawn quality was significantly reduced compared to Control (Chi2 $=14.60 ; p=0.006)$. GLM analysis indicated that these trends and differences were due to the reduction of the spawn number in class $80 \%-100 \%$ for LO- $0.3 \mathrm{X}$ and LO- $1 \mathrm{X}$ ( $p=0.09$ and $p=0.05$ respectively).

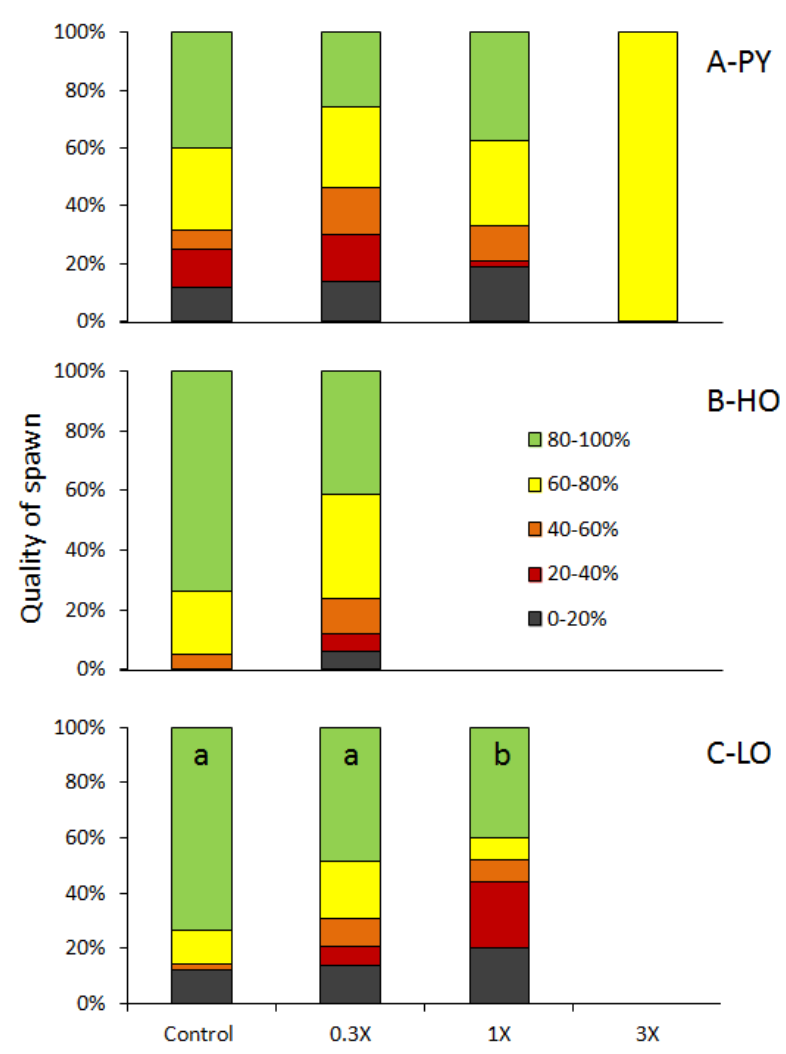

Figure 2. Spawns quality. Group-spawns obtained from adults exposed to pyrolitic (PY) (A), heavy oil (HO) (B) and light oil (LO) (C) diets were classified according to their fertilization rates (see insert in $(\mathbf{B}))$. In $(\mathbf{C})$, different letters indicate significant difference $(p<0.05)$.

In order to evaluate if reproduction disruption could be ascribed to a particular sex and so gain insight into mechanisms, we performed crosses between exposed and non-exposed fish. This was performed using HO-1X and LO-3X fish. Contrary to what was observed with homogenous fish, we obtained spawns for all crosses involving contaminated fish albeit with various success (Figure 3). Spawning success for female Control/male Control crosses was obtained in 9 assays out of $16(56.3 \%)$. Spawning success for female Control/male HO-1X crosses was not different $(64.3 \%$; $p=0.72$ ). In contrast, in female HO- $1 \mathrm{X} /$ male Control crosses, the success was significantly reduced compared to Control $(19.0 \% ; p<0.05)$. In the case of LO-3X crosses, the situation was different with a trend to decrease for female Control/male LO-3X $(25.0 \% ; p=0.09)$ and a very significant decrease for the opposite cross female LO-3X/male Control with only one spawn obtained out of 24 assays $(4.2 \%$; 
$p<0.001$ ). When further qualifying the obtained spawns, only one spawn of the female LO-3X/male Control cross was excluded from the analysis; the only significant difference obtained was the number of fertilized eggs obtained in the female Control/male LO-3X crosses which was significantly reduced $(\mathrm{KW}=14.95 ; p=0.02$ and post-hoc test $p=0.04)$, resulting in a fertilization rate of $7 \%$ which is approximately tenfold lower compared to other conditions $(60 \%-84 \%)$.
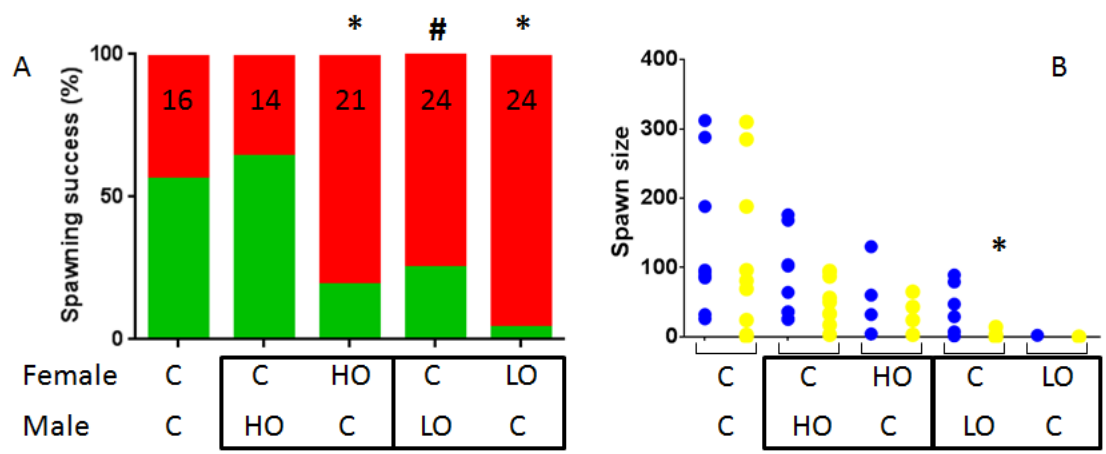

Figure 3. Qualification of Control/contaminated spawns. Spawning success of pairwise mating using fish from different conditions. Successful spawns are indicated in green while unsuccessful ones are in red. The number of assays is indicated in each bar (A); Number of eggs (blue) and fertilized eggs (yellow) of each successful spawn $(\mathbf{B}) .{ }^{*}$ indicates success differing from Control homogenous pairs $(p<0.05)$ and ${ }^{\#}$ trend to a difference $(p<0.1)$.

\subsection{Histological Analysis}

Histological analyses were performed to assess the ovaries' structure, morphology and functionality. The ovaries' overall structure was affected in female exposed but these disruptions differed depending on the fraction (Figure 4).
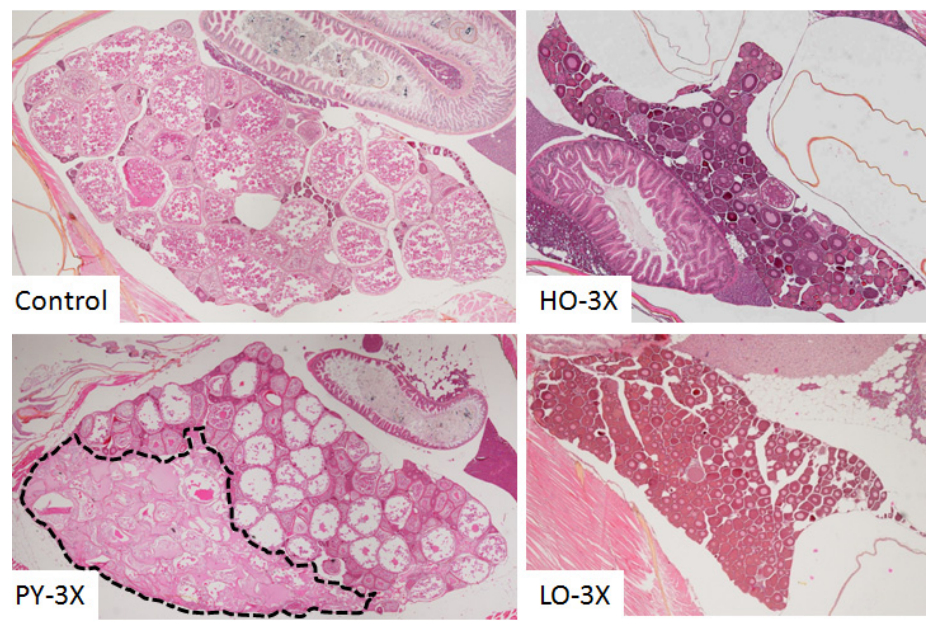

Figure 4. Ovary morphology. Representative pictures of ovaries sampled from Control, PY-3X, HO-3X and LO-3X females. The dotted line delimits disrupted area in PY-3X ovary.

Ovaries from control females presented an even distribution of follicles at all stages of maturation. All stages of follicles were also found in the ovary from females exposed to PY-3X diet which presented large areas of disrupted morphology which did not correspond to atretic follicles but rather degenerating areas. The surface percentage of these degenerating areas increased with PY concentration (Figure $5 ; F=4.81 ; p=0.007$ ). This kind of degenerating area was not found in ovaries from $\mathrm{HO}-3 \mathrm{X}$ and LO-3X fish. 


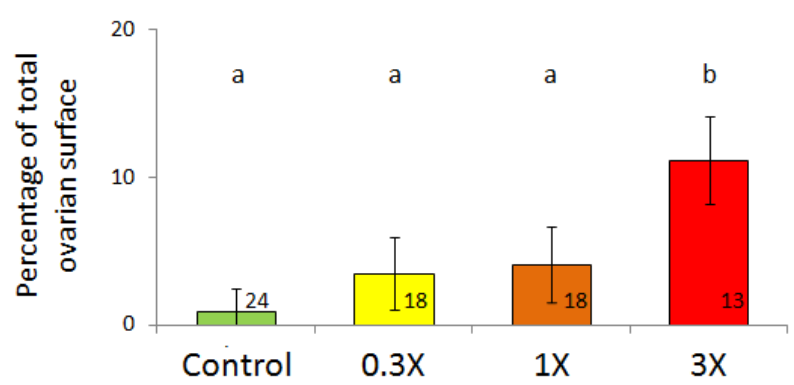

Figure 5. Surface of degenerating areas in PY fish ovaries (\% of total ovarian surface). Mean \pm SEM, different letters indicate significant difference $(p<0.05)$. The number of individuals analyzed is indicated in each bar.

Ovaries from females exposed to petrogenic fractions presented a significantly reduced number of maturing follicles (Figure 4). To quantify this disruption, follicles were counted according to their stage (Figure 6). In PY ovaries at $9 \mathrm{mpf}$, a slight increase in the proportion of F1 was observed in PY-0.3X ovaries. In contrast, a slight reduction of F4 was observed for PY-0.3X and PY-3X fish. More important disruptions were observed in $\mathrm{HO}$ and $\mathrm{LO}$ females. A significant increase of $\mathrm{F} 1$ was observed in $\mathrm{HO}-3 \mathrm{X}$ and LO-3X and to a lesser extent in LO-0.3X. In contrast, a slight decrease of F1 was observed in HO-0.3X and LO-1X. The percentage of some intermediate follicles was increased, F2 for HO-0.3X and $\mathrm{HO}-1 \mathrm{X}$ as well as F3 for LO-1X or decreased F3 for HO-1X. The case of F4 is clearer with a significant decrease of mature follicles in ovaries from HO-1X, HO-3X and LO-3X.

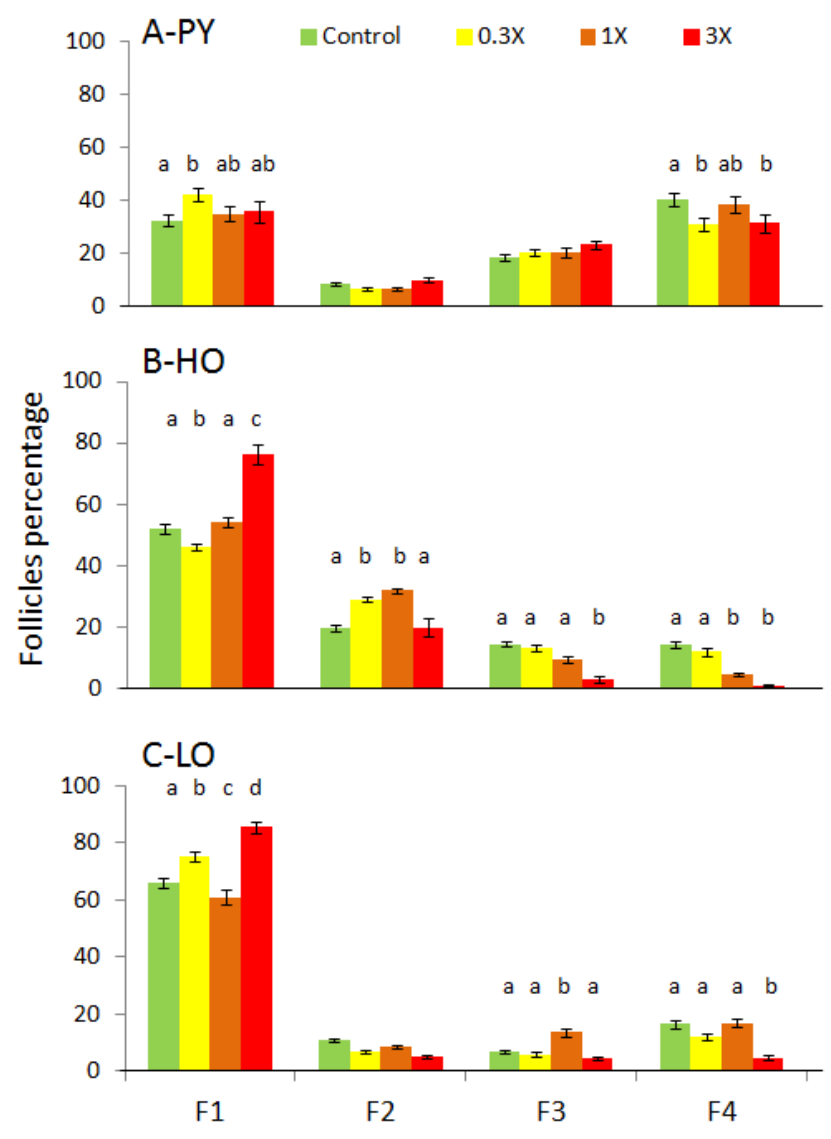

Figure 6. Follicles distribution according to their stage. Follicles were classified according to their maturation: pre-vitellogenic stages (F1 and F2); post-vitellogenic stage (F3) and mature follicles (F4). Percentage of follicles in each class, mean \pm SEM. Different letters indicate significant difference compared to the relative control $(p<0.05)$. 
Testis structure and morphology were also analyzed at the same age. Testicular hypoplasia (Figure 7A,B) has been observed in males exposed to HO-1X ( $n=3 ; 6.4 \%$ of analysed males), in HO-3X $(n=9 ; 42.9 \%)$ as well as in LO-3X $(n=2 ; 7.4 \%)$. In addition to these functional disruptions, some seminoma have been identified in $1 X$ or $3 X$ concentrations in all fractions while none has been found in control fish. These very invasive tumors were described in more detail in Larcher et al. [31]. Finally, one ovotestis has been identified in $\mathrm{HO}-3 \mathrm{X}$ treatment (Figure 7C).
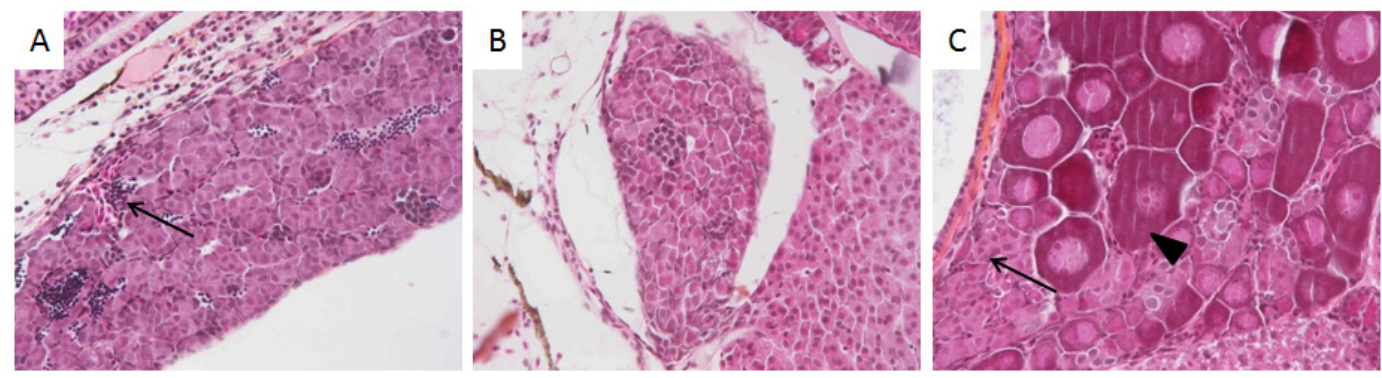

Figure 7. Testis functional disruptions. Testicular hypoplasia revealed by the low number of spermatozoa (A) or their absence (B). Ovotestis observed in HO-3X with coexistence of immature follicles (arrowhead) and spermatogonia (arrow) (C).

\subsection{Genes Expression Analysis}

Expression of genes encoding estrogens receptors (esr1, esr $2 a$ and esr $2 b$ ) and ovarian aromatase (cyp19a1a) was assessed in ovaries sampled at $9 \mathrm{mpf}$ (Table 2). Regarding estrogens receptors, the esr 1 gene is up-regulated in ovaries of PY-1X $(p<0.05)$ and HO-0.3X $(p<0.05)$ while esr2a is up-regulated in HO-0.3X $(p<0.01)$ and HO-1X $(p<0.05)$. In contrast, esr $2 b$ is down-regulated in LO- $1 \mathrm{X}(p<0.05)$ and just above significance threshold for LO-3X $(p=0.053)$. Ovarian aromatase is also up-regulated in ovaries of PY-1X $(p<0.05)$ and HO-0.3X $(p<0.05)$ but down-regulated in ovaries of LO-3X.

Table 2. qPCR genes expression analysis in ovary of exposed fish.

\begin{tabular}{|c|c|c|c|c|c|c|}
\hline \multirow{2}{*}{ PY } & \multicolumn{2}{|c|}{$0.3 X$} & \multicolumn{2}{|c|}{$1 X$} & \multicolumn{2}{|c|}{$3 X$} \\
\hline & Fold Change & $95 \% \mathrm{CI}$ & Fold Change & $95 \%$ CI & Fold Change & $95 \%$ CI \\
\hline esr1 & 0.866 & $0.467-1.523$ & 1.871 & $0.738-5.330$ & 1.52 & $0.471-6.460$ \\
\hline esr $2 a$ & 1.225 & $0.329-3.330$ & 1.047 & $0.254-3.257$ & 0.798 & $0.214-2.638$ \\
\hline$e s r 2 b$ & 0.906 & $0.329-2.009$ & 1.24 & $0.531-2.990$ & 1.028 & $0.269-4.046$ \\
\hline cyp19a1a & 1.265 & $0.373-5.167$ & 2.142 & $0.632-7.352$ & 1.094 & $0.287-4.970$ \\
\hline \multirow{2}{*}{ HO } & \multicolumn{2}{|c|}{$0.3 X$} & \multicolumn{2}{|c|}{$1 X$} & \multicolumn{2}{|c|}{$3 x$} \\
\hline & Fold Change & $95 \%$ CI & Fold Change & $95 \% \mathrm{CI}$ & Fold Change & $95 \% \mathrm{CI}$ \\
\hline esr1 & 3.133 & $1.517-9.697$ & 1.257 & $0.488-4.096$ & Not done & \\
\hline esr $2 a$ & 5.029 & $3.323-9.452$ & 3.043 & $1.182-5.624$ & Not done & - \\
\hline$e s r 2 b$ & Not done & & Not done & & Not done & \\
\hline cyp19a1a & 1.666 & $0.573-3.221$ & 1.265 & $0.686-3.414$ & Not done & \\
\hline \multirow{2}{*}{ LO } & \multicolumn{2}{|c|}{$0.3 X$} & \multicolumn{2}{|c|}{$1 X$} & \multicolumn{2}{|c|}{$3 X$} \\
\hline & Fold Change & $95 \%$ CI & Fold Change & $95 \% \mathrm{CI}$ & Fold Change & $95 \%$ CI \\
\hline esr1 & 0.89 & $0.339-2.869$ & 0.599 & $0.182-2.501$ & 0.642 & $0.220-2.272$ \\
\hline esr $2 a$ & 0.847 & $0.120-8.124$ & 0.951 & $0.354-4.418$ & 1.26 & $0.378-8.276$ \\
\hline$e s r 2 b$ & 0.747 & $0.315-2.530$ & 0.455 & $0.125-1.870$ & 0.486 & $0.185-1.661$ \\
\hline cyp19a1a & 1.013 & $0.041-5.064$ & 0.483 & $0.054-3.590$ & 0.336 & $0.061-1.206$ \\
\hline
\end{tabular}

In testis, genes expression has been monitored for two genes involved in the steroidogenesis pathway (cyp17a1 and hsd11b3) and two genes are an indicator of spermatogenesis (amh and spag8; 
Table 3). In testis of exposed fish, spag8 is down-regulated in PY-0.3X $(p<0.01)$ and PY-1X $(p<0.01)$ while cyp17a1 is down-regulated in PY-0.3X $(p<0.01)$, HO-0.3X $(p<0.01)$ and H0-1X $(p<0.01)$. In contrast, cyp17a1 is up-regulated in L0-1X $(p<0.01)$ as well as amh in L0-0.3X $(p<0.05)$ and L0-1X $(p<0.01)$ and just above the significance threshold for LO-3X $(p=0.065)$.

Table 3. qPCR genes expression analysis in testis of exposed fish.

\begin{tabular}{|c|c|c|c|c|c|c|}
\hline \multirow{2}{*}{ PY } & \multicolumn{2}{|c|}{$0.3 X$} & \multicolumn{2}{|c|}{$1 X$} & \multicolumn{2}{|c|}{$3 X$} \\
\hline & Fold Change & $95 \%$ CI & Fold Change & $95 \%$ CI & Fold Change & $95 \%$ CI \\
\hline$a m h$ & 0.777 & $0.484-1.189$ & 0.594 & $0.439-0.803$ & 1.422 & $0.729-3.459$ \\
\hline spag8 & 0.449 & $0.280-0.776$ & 0.509 & $0.382-0.677$ & 0.751 & 0.483-1.109 \\
\hline cyp17a1 & 0.528 & $0.207-1.623$ & 0.447 & $0.329-0.609$ & 0.948 & $0.385-1.948$ \\
\hline$h s d 11 b 3$ & 0.632 & $0.337-1.241$ & 0.885 & $0.552-1.437$ & 0.763 & $0.472-1.334$ \\
\hline \multirow{2}{*}{ HO } & \multicolumn{2}{|c|}{$0.3 X$} & \multicolumn{2}{|c|}{$1 X$} & \multicolumn{2}{|c|}{$3 X$} \\
\hline & Fold Change & $95 \%$ CI & Fold Change & $95 \%$ CI & Fold Change & - \\
\hline$a m h$ & 0.885 & $0.614-1.534$ & 0.739 & $0.191-1.600$ & Not done & \\
\hline spag8 & 1.496 & $0.764-2.857$ & 1.381 & $0.600-3.074$ & Not done & - \\
\hline cyp17a1 & 0.23 & $0.091-0.708$ & 0.354 & $0.208-0.750$ & Not done & \\
\hline$h s d 11 b 3$ & 0.917 & $0.578-1.644$ & 0.93 & $0.603-1.611$ & Not done & \\
\hline \multirow{2}{*}{ LO } & \multicolumn{2}{|c|}{$0.3 X$} & \multicolumn{2}{|c|}{$1 X$} & \multicolumn{2}{|c|}{$3 x$} \\
\hline & Fold Change & $95 \%$ CI & Fold Change & $95 \%$ CI & Fold Change & $95 \%$ CI \\
\hline$a m h$ & 2.109 & $1.031-3.978$ & 1.723 & $1.369-2.061$ & 1.864 & $1.173-3.549$ \\
\hline spag8 & 1.127 & $0.800-1.653$ & 1.078 & 0.995-1.178 & 0.667 & $0.311-1.074$ \\
\hline cyp17a1 & 0.977 & $0.470-2.123$ & 1.39 & $1.008-1.971$ & 1.104 & $0.574-2.174$ \\
\hline$h s d 11 b 3$ & 1.362 & $0.700-2.230$ & 1.331 & $0.943-1.995$ & 0.918 & $0.541-1.530$ \\
\hline
\end{tabular}

Fold change is indicated relative to ovaries sampled in Control females. The $95 \%$ confidence interval provided by REST software is provided (95\% CI). Values in bold are significantly different compared to expression in Control fish.

Fold change is indicated relative to testis sampled in Control males. The $95 \%$ confidence interval provided by REST software is provided $(95 \% \mathrm{CI})$. Values in bold are significantly different compared to expression in Control fish.

\section{Discussion}

\subsection{Reproductive Disruptions}

Several reproductive traits monitored in this study were disrupted upon lifelong exposure to PAHs fractions all contributing to a reduction in reproduction success. Some differences were observed between fractions and will be specifically discussed later on. The most affected trait is the spawning success evaluated as the number of spawns collected over a period of time. For all fractions, a complete failure of spawning was observed for the $3 X$ concentration (except PY-3X; 1 spawn out of 87 attempts). In addition, zero spawn was obtained for HO-1X. Otherwise, a general trend towards a dose-effect reduction in spawning success could be observed.

Tank replicates were established before hatching and remained unchanged during the whole experiment in order not to perturb group composition in each rearing tank. This was a methodological choice based on the fact that visual and olfactive cues have been shown to be important for reproduction [37]. Because sex is plastic in zebrafish [38], this could result in groups with biased sex-ratio which was indeed observed in our experimental groups with a females to males (F/M) ratio ranging from 3.32 (PY Control) to 0.51 (HO-1X) while the overall mean ratio was 1.15. These differences in sex-ratio may explain some differences in terms of spawning success between diets. When considering only Control conditions, HO-Control with a F/M ratio of 0.54 had a $51 \%$ 
spawning success compared to PY-Control (F/M = 3.32; Success =69\%) or LO-Control (F/M = 1.19; Success $=77 \%$ ) which suggests that if a low ratio could result in a lower spawning success there is no obvious correlation. Considering relative sex-ratio and spawning success, this may have only lead to an underestimation of spawning success for L0-0.3X condition. To further characterize reproduction traits, spawn's size normalized per number of females and successful assays in each tank revealed an additional disruption for LO-1X, while spawn's size from HO- and LO-0.3X were intermediate between Control and $1 X$ conditions. Finally, fertilization rates decreased significantly for LO-1X spawns. Altogether this resulted in a dramatic decrease in reproductive output for exposed fish, as evaluated by the cumulative number of produced fertilized eggs. The analysis of all those traits are rarely considered altogether, especially in such kinds of ecotoxicological studies. Therefore, results will be globally discussed in the light of relevant studies which have, however, mostly been performed using individual PAHs. Indeed, exposures to individual PAHs have been shown to reduce the number of eggs in several fish species [19,39-42] while an exposure to benzo[a]pyrene produced a decreased fertilization rate in mummichog [43]. In contrast, an exposure of Japanese medaka to phenanthrene produced no modification of the daily number of eggs spawned and fertilization rate did not change, with the exception of one intermediate concentration [17].

The paucity of information on reproduction functionality is puzzling owing the number of studies reporting the disruption of biomarkers related to reproduction after exposure to PAHs. If some studies have reported no gonadal disruptions $[17,43]$, some experimental exposure to PAHs as well as analysis of fish collected in the field in PAH-contaminated areas revealed disruption of gonadal structure or reproduction-related biomarkers, which could help to understand the presently observed reproductive defects. For example, some studies showed that fish exposure to PAHs results in gonadal structure disruption indicative of maturation defects in females $[39,40,44]$ and in males $[44,45]$. Our results are in agreement with these articles, revealing a decrease in ovary maturation as shown by a decrease in mature follicles (F4) proportion in female exposed to 3X concentration for all fractions and post-vitellogenic follicles (F3) for HO-3X females. In the case of PY females, we have also identified degeneration areas in ovaries, the relative surface of which increased with PY concentration. In the case of males, the observed defects (hypoplasia in a small proportion of LO-3X and HO-1X and in a high proportion ( $42 \%$ ) of $\mathrm{HO}-3 \mathrm{X}$ males) have already been mentioned in cod after exposure to produced water [44]. Further, one ovo-testis was also found in one individual morphologically identified as a male. With regard to this latter observation, the occurrence of such histological disruption may have been underestimated because during sampling we targeted females and males on the basis of clear morphological differences; therefore, individuals which could not be ascribed to a sex were not sampled. Finally, in addition to these maturation defects, seminoma have been observed in PY-3X, $\mathrm{HO}-1 \mathrm{X}$ and LO-3X as previously reported [31].

Crosses performed between Control and exposed fish (HO-1X and LO-3X) suggest that spawning success is mainly driven by females, at least for the petrogenic fractions investigated. Beyond strictly reproductive defects, this could be due to behavioral disruptions which we have previously reported [32].

Overall, the present results showed that lifelong exposures to environmentally relevant PAHs fractions lead to reproductive dysfunctions and that these defects depended on the fraction used. Differences could be seen both on defects' severity with petrogenic fractions producing more dramatic effects than PY fraction, and on defects nature with some specific insults such as ovaries degeneration after PY exposure or fertilization rate decrease after LO exposure. Such differences suggest the triggering of different molecular mechanisms.

\subsection{Underlying Mechanisms}

Reproduction defects can be the result of a general physiological dysfunction. In regard to this, it should be said that several physiological traits have been measured on the same fish and that, beyond the behavioral disruptions already mentioned, growth has been shown to be reduced after exposure, 
as well as the expression of some digestive enzyme and the ability to cope with food deprivation [33]. This reduced growth (along with disrupted condition indices) has already been observed upon exposure to PAHs [24,46-48] and could also have contributed to reduced reproduction output.

Exposure to PAHs usually results in a decrease in estradiol (E2) and 11-ketotestosterone (T), this has been observed after exposure to individual compounds $[26,43,49]$ and more complex mixtures such as Produced water [44]. However, in other cases, an increase is observed [50] or E2 is reduced while T is increased [41]. In some cases, the situation is more complex with non-monotonic responses [27,45]. Finally, in some cases no change is observed after exposure to individual compounds or complex mixtures [16,51]. Altogether, these results suggest that PAHs can have endocrine disrupter activity while the estrogenic and/or anti-estrogenic property is not clear. In our cases, E2, T and vitellogenin circulating concentrations have been measured but no clear conclusion could be drawn (data not shown). In order to gain insight into molecular mechanisms underlying the observed reproduction defects, we have analyzed the expression of a set of genes involved in different functions (steroid pathways, gonad differentiation and maintenance) in gonads sampled at 9 mpf. Gene's expression changes not follow a dose-response scheme, in particular very few changes were observed with the $3 \mathrm{X}$ concentration (not performed for $\mathrm{HO}$ since no more fish were available at this age likely resulting from an excessive toxicity). According to esr regulation by E2 [52], the activation in ovaries of esr1 and esr2a expression in PY-1X and HO-0.3X and 1X and of cyp19a1a in PY-1X as well as the decrease in esr $2 b$ in LO-1X are indicative of an estrogenic activity of these fractions in females. Another explanation could be that AhR directly activates the expression of estrogen receptors [53,54]. The reduction of cyp17a1 expression in testis of PY-0.3X and $\mathrm{HO}$ males is also indicative of estrogenic activity in males according to the known regulation of Cyp17a1 protein by E2 in zebrafish [55]. In testis, spag8 is expressed in the acrosomal region of spermatozoa and in germ cells starting in spermatocytes [56] and its expression is positively regulated by androgen receptor agonists and negatively by antagonists [57]. The observed decrease in spag 8 expression may be indicative of anti-androgen activity in PY exposed fish. This combination of estrogenic and anti-androgenic activity may explain the gonadal degeneration in PY females' ovaries; indeed both an excess of estrogen and a decrease in testosterone have been shown to promote ovarian structural disruption [58-60]. Besides, it has been shown in mouse that PAHs exposure promoted ovarian failure through AhR-mediated bax activation [61]. This pathway could underpin the specific disruption observed in PY ovaries since PY fraction contains high proportion of high molecular weight PAHs which are supposed to be AhR ligands. This mechanism could also explain why, while in $\mathrm{HO}$ and LO the decrease in the number of mature follicle is compensated by a higher proportion of pre-vitellogenic follicles, this is not the case in PY-3X ovaries. Indeed, it has also been shown that PAHs triggering AhR such as PY fraction (and HO to a lower extent) also specifically destroys primordial oocytes [62]. On the male side, the regulation of amh expression in testis is of particular interest. Indeed, in mammals, this gene is expressed during gonadal development and later almost exclusively in Sertoli cells during fetal and prepubertal stages. Later on, amh remains expressed but at a lower level in relation with spermatogenesis. The up-regulation of $a m h$ in testis of LO males could indicate a persistent defect in testis differentiation and/or spermatogenesis and may explain the specific and dramatic lower fertilization rates observed in pair-wise crosses between females Control and males LO-3X. Altogether, these results are evocative of endocrine disruption but also suggest that in some cases, reproductive dysfunction may be the consequence of gonad differentiation and/or maturation defects leading to a high proportion of immature individuals. In this context, the single ovo-testis observed in HO-3X may be seen as a result of an incomplete switch from ovary-like pre-differentiation gonad to testis rather than a sex-reversal. As in the case of reproductive traits, molecular analyses point out differences between fraction's effects, and PY and HO appear to share common pathways likely triggered by AhR while LO fraction would be acting through a yet-unidentified pathway. 


\subsection{Environmental Relevance}

Field monitoring as well as environmental assessment after an oil spill have demonstrated the important consequences of PAHs exposure on ecosystems in general and fish in particular [63-65]. Identified effects cover a wide range of physiological functions or processes and include reproduction or reproductive traits defects. In the case of an oil spill, the situation is simpler since PAHs source is clearly identified. However, oil denominations cover a large range of mixtures, the compositions of which depend on extraction localization as well as refining level. This is exemplified by the two petrogenic fractions used in this study. HO fraction contained $31 \%$ of high molecular weight PAHs while they represent only $6 \%$ of LO fraction but both contained high proportion of methylated PAHs (45\%-59\%) [33]. The situation is less simple in areas where PAHs sources are diverse, often resulting from human activity. In this case, PAHs can be of both pyrolytic and petrogenic origin and enter aquatic environments through the deposition of atmospheric emissions or from soil runoff. PY fraction extracted from sediment collected in the Seine River is representative of such PAHs mixture encountered in urbanized areas. PY fraction contained a very high proportion of high molecular weight PAHs (82\%) and very few methylated derivatives (5\%) [33]. Another major difference with oil spill is that, in the latter case, PAHs emission is constant, leading to chronic exposure. Nonetheless, after acute exposure during an oil spill, and despite cleaning operations, a secondary chronic exposure to lower level of PAHs persist over a long time period as this has been extensively studied after the Exxon Valdez spill [64] converging toward similar issues as in urbanized areas.

The concentration of PAHs in the biota therefore varies depending on the surrounding concentrations, in particular in sediment, and on a trophic level. For example, the total concentration of US-EPA 16 PAHs in the copepod Eurytemora affinis in the Seine Estuary can reach $3.9 \mu g \cdot \mathrm{g}^{-1}$ [66] and in mussels can be as high as $1.6 \mu \mathrm{g} \cdot \mathrm{g}^{-1}$ [67]. In the case of acute accidental exposure, the concentration in mussels can be even higher, for example $3.0 \mu \mathrm{g} \cdot \mathrm{g}^{-1}$ after the Erika oil spill [68] and above $14 \mu \mathrm{g} \cdot \mathrm{g}^{-1}$ after Exxon Valdez oil spill [69]. PAHs concentrations in 1X diets used within the frame of this study are in the (4.7-6.7 $\mu \mathrm{g} . \mathrm{g}-1 \mathrm{dw})$ range [33] and therefore fall into concentration encountered in contaminated areas. Fish can be exposed to PAHs through several routes including the trophic route, which has been shown to be an important route [9-11].

\section{Conclusions}

Field monitoring has revealed correlation between PAHs concentrations in the environment (or metabolites in individuals) whatever PAHs origin, and reproductive defects in fish [11,20-25,29,63,70,71]. This kind of monitoring analysis is essential for the environment but biomarkers often only allow raw estimates of disruptions and whatever actual reproduction output cannot be measured. Effects on population are therefore often only reached through modeling approaches [1,72]. Moreover, we believe that complementary approaches such as the one presented here, are suitable to investigate environmental exposure to complex mixtures and that, even if we conducted controlled experimental exposures, our results are pinpointing serious alteration of the recruitment success in the wild fish population. Further characterizations of the pathways are needed to refine and develop smarter biomarkers and we believe that zebrafish could provide a useful toolbox for this purpose as well as for transgenerational effects assessment since offspring insult has been shown upon exposure to PAHs $[41,46,73]$.

Supplementary Materials: The following are available online at www.mdpi.com/2305-6304/4/4/26/s1. Table S1: Detailed concentration of individual PAHs in produced diets.

Acknowledgments: We thank Didier Leguay for his help and Patrick Babin for fruitful discussions. This study was financially supported by the ANR project ConPhyPoP (CES 09_002) and CPER A2E. This project is co-financed by the European Union with the European Fund of Regional Development. Doctoral grant was received from the Région Poitou-Charentes and Institut Français de Recherche pour l'Exploitation de la Mer by C.V. This work was part of the LABEX COTE cluster of excellence continental to coastal ecosystems. 
Author Contributions: T.L., H.B., M.-L.B. and X.C. conceived and designed the experiments; All Authors contributed to the experiments; C.V., T.L., B.D., H.B., M.-L.B. and X.C. analyzed the data; C.V., M.-L.B. and X.C. wrote the paper.

Conflicts of Interest: The authors declare no conflict of interest.

\section{References}

1. Rochette, S.; Rivot, E.; Morin, J.; Mackinson, S.; Riou, P.; Le Pape, O. Effect of nursery habitat degradation on flatfish population: Application to Solea solea in the eastern channel (western europe). J. Sea Res. 2010, 64, 34-44. [CrossRef]

2. Latimer, J.S.; Zheng, J. The sources, transport, and fate of PAHs in the marine environment. In PAHs: An Ecotoxicological Perspective; John Wiley \& Sons, Ltd.: Chichester, UK, 2003; pp. 7-33.

3. Shen, H.; Huang, Y.; Wang, R.; Zhu, D.; Li, W.; Shen, G.; Wang, B.; Zhang, Y.; Chen, Y.; Lu, Y.; et al. Global atmospheric emissions of polycyclic aromatic hydrocarbons from 1960 to 2008 and future predictions. Environ. Sci. Technol. 2013, 47, 6415-6424. [CrossRef] [PubMed]

4. Zhang, Y.; Tao, S. Global atmospheric emission inventory of polycyclic aromatic hydrocarbons (PAHs) for 2004. Atmos. Environ. 2009, 43, 812-819. [CrossRef]

5. Hylland, K. Polycyclic aromatic hydrocarbon (PAH) ecotoxicology in marine ecosystems. J. Toxicol. Environ. Health Part A 2006, 69, 109-123. [CrossRef] [PubMed]

6. Baumard, P.; Budzinski, H.; Garrigues, P.; Sorbe, J.C.; Burgeot, T.; Bellocq, J. Concentrations of PAHs (polycyclic aromatic hydrocarbons) in various marine organisms in relation to those in sediments and to trophic level. Mar. Pollut. Bull. 1998, 36, 951-960. [CrossRef]

7. Cachot, J.; Geffard, O.; Augagneur, S.; Lacroix, S.; Le Menach, K.; Peluhet, L.; Couteau, J.; Denier, X.; Devier, M.H.; Pottier, D.; et al. Evidence of genotoxicity related to high PAH content of sediments in the upper part of the seine estuary (Normandy, France). Aquat. Toxicol. 2006, 79, 257-267. [CrossRef] [PubMed]

8. Benlahcen, K.T.; Chaoui, A.; Budzinski, H.; Bellocq, J.; Garrigues, P. Distribution and sources of polycyclic aromatic hydrocarbons in some mediterranean coastal sediments. Mar. Pollut. Bull. 1997, 34, 298-305. [CrossRef]

9. Johnson, L.L.; Ylitalo, G.M.; Arkoosh, M.R.; Kagley, A.N.; Stafford, C.; Bolton, J.L.; Buzitis, J.; Anulacion, B.F.; Collier, T.K. Contaminant exposure in outmigrant juvenile salmon from pacific northwest estuaries of the united states. Environ. Monit. Assess. 2007, 124, 167-194. [CrossRef] [PubMed]

10. Varanasi, U.; Casillas, E.; Arkoosh, M.R.; Hom, T.; Misitano, D.; Brown, D.W.; Chan, S.-L.; Collier, T.K.; McCain, B.B.; Stein, J.E. Contaminant Exposure and Associated Biological Effects in Juvenile Chinook Salmon (Oncorhynchus tshawytscha) from Urban and Nonurban Estuaries of Puget Sound; NOAA Fisheries: Seattle, WA, USA, 1993; p. 112.

11. Yanagida, G.K.; Anulacion, B.F.; Bolton, J.L.; Boyd, D.; Lomax, D.P.; Paul Olson, O.; Sol, S.Y.; Willis, M.; Ylitalo, G.M.; Johnson, L.L. Polycyclic aromatic hydrocarbons and risk to threatened and endangered chinook salmon in the lower columbia river estuary. Arch. Environ. Contam. Toxicol. 2012, 62, 282-295. [CrossRef] [PubMed]

12. He, J.H.; Gao, J.M.; Huang, C.J.; Li, C.Q. Zebrafish models for assessing developmental and reproductive toxicity. Neurotoxicol. Teratol. 2014, 42, 35-42. [CrossRef] [PubMed]

13. Hinton, D.E.; Kullman, S.W.; Hardman, R.C.; Volz, D.C.; Chen, P.-J.; Carney, M.; Bencic, D.C. Resolving mechanisms of toxicity while pursuing ecotoxicological relevance? Mar. Pollut. Bull. 2005, 51, 635-648. [CrossRef] [PubMed]

14. Leon-Olea, M.; Martyniuk, C.J.; Orlando, E.F.; Ottinger, M.A.; Rosenfeld, C.S.; Wolstenholme, J.T.; Trudeau, V.L. Current concepts in neuroendocrine disruption. Gen. Comp. Endocrinol. 2014, 203, 158-173. [CrossRef] [PubMed]

15. Kloas, W.; Urbatzka, R.; Opitz, R.; Wurtz, S.; Behrends, T.; Hermelink, B.; Hofmann, F.; Jagnytsch, O.; Kroupova, H.; Lorenz, C.; et al. Endocrine disruption in aquatic vertebrates. Ann. N. Y. Acad. Sci. 2009, 1163, 187-200. [CrossRef] [PubMed] 
16. Seruto, C.; Sapozhnikova, Y.; Schlenk, D. Evaluation of the relationships between biochemical endpoints of PAH exposure and physiological endpoints of reproduction in male california halibut (Paralichthys californicus) exposed to sediments from a natural oil seep. Mar. Environ. Res. 2005, 60, 454-465. [CrossRef] [PubMed]

17. Horng, C.Y.; Lin, H.C.; Lee, W. A reproductive toxicology study of phenanthrene in medaka (Oryzias latipes). Arch. Environ. Contam. Toxicol. 2010, 58, 131-139. [CrossRef] [PubMed]

18. Tollefsen, K.E.; Sundt, R.C.; Beyer, J.; Meier, S.; Hylland, K. Endocrine modulation in atlantic cod (Gadus morhua L.) exposed to alkylphenols, polyaromatic hydrocarbons, produced water, and dispersed oil. J. Toxicol. Environ. Health A 2011, 74, 529-542. [CrossRef] [PubMed]

19. Tilghman Hall, A.; Oris, J.T. Anthracene reduces reproductive potential is maternally transferred during long-term exposure in fathead minnows. Aquat. Toxicol. 1991, 19, 249-264. [CrossRef]

20. Bugel, S.M.; White, L.A.; Cooper, K.R. Impaired reproductive health of killifish (Fundulus heteroclitus) inhabiting Newwark bay, NJ, a chronically contaminated estuary. Aquat. Toxicol. 2010, 96, 182-193. [CrossRef] [PubMed]

21. Casillas, E.; Misitano, D.; Johnson, L.L.; Rhodes, L.D.; Collier, T.K.; Stein, J.E.; McCain, B.B.; Varanasi, U. Inducibility of spawning and reproductive success of female english sole (Praphrys vetulus) from urban and nonurban areas of Puget Sound, Washington. Mar. Environ. Res. 1991, 31, 99-122. [CrossRef]

22. Johnson, L.L.; Stein, J.E.; Collier, T.K.; Casillas, E.; Varanasi, U. Indicators of reproductive development in prespawning female winter flounder (Pleuronectes americanus) from urban and non-urban estuaries in the northeast United States. Sci. Total Environ. 1994, 141, 241-260. [CrossRef]

23. Kiceniuk, J.W.; Khan, R.A. Effect of petroleum hydrocarbons on atlantic cod, Gadus morhua, following chronic exposure. Can. J. Zool. 1987, 65, 490-494. [CrossRef]

24. Ridgway, L.L.; Chapleau, F.; Comba, M.E.; Backus, S.M. Population characteristics and contaminant burdens of the white sucker (Catostomus commersoni) from the St. Lawrence river near Cornwall, Ontario and Massena, New York. J. Great Lakes Res. 1999, 25, 567-582. [CrossRef]

25. Tetreault, G.R.; McMaster, M.E.; Dixon, D.G.; Parrott, J.L. Using reproductive endpoints in small forage fish species to evaluate the effects of Athabasca oil sands activities. Environ. Toxicol. Chem. 2003, 22, 2775-2782. [CrossRef] [PubMed]

26. Monteiro, P.R.; Reis-Henriques, M.A.; Coimbra, J. Plasma steroid levels in female flounder (Platichthys flesus) after chronic dietary exposure to single polycyclic aromatic hydrocarbons. Mar. Environ. Res. 2000, 49, 453-467. [CrossRef]

27. Arukwe, A.; Nordtug, T.; Kortner, T.M.; Mortensen, A.S.; Brakstad, O.G. Modulation of steroidogenesis and xenobiotic biotransformation responses in zebrafish (Danio rerio) exposed to water-soluble fraction of crude oil. Environ. Res. 2008, 107, 362-370. [CrossRef] [PubMed]

28. Evanson, M.; Van Der Kraak, G.J. Stimulatory effects of selected PAHs on testosterone production in goldfish and rainbow trout and possible mechanisms of action. Comp. Biochem. Physiol. C Toxicol. Pharmacol. 2001, 130, 249-258. [CrossRef]

29. Sol, S.Y.; Johnson, L.L.; Horness, B.H.; Collier, T.K. Relationship between oil exposure and reproductive parameters in fish collected following the Exxon Valdez oil spill. Mar. Pollut. Bull. 2000, 40, 1139-1147. [CrossRef]

30. Truscott, B.; Walsh, J.M.; Burton, M.P.; Payne, J.F.; Idler, D.R. Effect of acute exposure to crude petroleum on some reproductive hormones in salmon and flounder. Comp. Biochem. Physiol. C Comp. Pharmacol. Toxicol. 1983, 75, 121-130. [CrossRef]

31. Larcher, T.; Perrichon, P.; Vignet, C.; Ledevin, M.; Le Menach, K.; Lyphout, L.; Landi, L.; Clerandeau, C.; Lebihanic, F.; Menard, D.; et al. Chronic dietary exposure of zebrafish to PAH mixtures results in carcinogenic but not genotoxic effects. Environ. Sci. Pollut. Res. Int. 2014, 21, 13833-13849. [CrossRef] [PubMed]

32. Vignet, C.; Le Menach, K.; Lyphout, L.; Guionnet, T.; Frere, L.; Leguay, D.; Budzinski, H.; Cousin, X.; Begout, M.L. Chronic dietary exposure to pyrolytic and petrogenic mixtures of PAHs causes physiological disruption in zebrafish-Part II: Behavior. Environ. Sci. Pollut. Res. Int. 2014, 21, 13818-13832. [CrossRef] [PubMed]

33. Vignet, C.; Le Menach, K.; Mazurais, D.; Lucas, J.; Perrichon, P.; Le Bihanic, F.; Devier, M.H.; Lyphout, L.; Frere, L.; Begout, M.L.; et al. Chronic dietary exposure to pyrolytic and petrogenic mixtures of PAHs causes physiological disruption in zebrafish-Part I: Survival and growth. Environ. Sci. Pollut. Res. Int. 2014, 21, 13804-13817. [CrossRef] [PubMed] 
34. Daouk, T.; Larcher, T.; Roupsard, F.; Lyphout, L.; Rigaud, C.; Ledevin, M.; Loizeau, V.; Cousin, X. Long-term food-exposure of zebrafish to PCB mixtures mimicking some environmental situations induces ovary pathology and impairs reproduction ability. Aquat. Toxicol. 2011, 105, 270-278. [CrossRef] [PubMed]

35. Spitsbergen, J.M.; Tsai, H.W.; Reddy, A.; Miller, T.; Arbogast, D.; Hendricks, J.D.; Bailey, G.S. Neoplasia in zebrafish (Danio rerio) treated with 7,12-dimethylbenz[a]anthracene by two exposure routes at different developmental stages. Toxicol. Pathol. 2000, 28, 705-715. [CrossRef] [PubMed]

36. Koç, N.D.; Aytekin, Y.; Yüce, R. Ovary maturatıon stages and histological investigation of ovary of the zebrafish (Danio rerio). Braz. Arch. Biol. Technol. 2008, 51, 513-522.

37. Gerlach, G.; Lysiak, N. Kin recognition and inbreeding avoidance in zebrafish, Danio rerio, is based on phenotype matching. Anim. Behav. 2006, 71, 1371-1377. [CrossRef]

38. Siegfried, K.R.; Nusslein-Volhard, C. Germ line control of female sex determination in zebrafish. Dev. Biol. 2008, 324, 277-287. [CrossRef] [PubMed]

39. Brown-Peterson, N.J.; Manning, C.S.; Brouwer, M.; Griffitt, R.J. Effects of pyrene exposure on sheepshead minnow (Cyprinodon variegatus) reproduction. J. Toxicol. Environ. Health Part A 2013, 76, 842-852. [CrossRef] [PubMed]

40. Sun, L.; Zuo, Z.; Chen, M.; Chen, Y.; Wang, C. Reproductive and transgenerational toxicities of phenanthrene on female marine medaka (Oryzias melastigma). Aquat. Toxicol. 2015, 162, 109-116. [CrossRef] [PubMed]

41. Pollino, C.A.; Georgiades, E.; Holdway, D.A. Physiological changes in reproductively active rainbowfish (Melanotaenia fluviatilis) following exposure to naphthalene. Ecotoxicol. Environ. Saf. 2009, 72, 1265-1270. [CrossRef] [PubMed]

42. Hoffmann, J.L.; Oris, J.T. Altered gene expression: A mechanism for reproductive toxicity in zebrafish exposed to benzo[a]pyrene. Aquat. Toxicol. 2006, 78, 332-340. [CrossRef] [PubMed]

43. Booc, F.; Thornton, C.; Lister, A.; Maclatchy, D.; Willett, K.L. Benzo[a]pyrene effects on reproductive endpoints in Fundulus heteroclitus. Toxicol. Sci. 2014, 140, 73-82. [CrossRef] [PubMed]

44. Sundt, R.C.; Bjorkblom, C. Effects of produced water on reproductive parameters in prespawning atlantic cod (Gadus morhua). J. Toxicol. Environ. Health A 2011, 74, 543-554. [CrossRef] [PubMed]

45. Sun, L.; Zuo, Z.; Luo, H.; Chen, M.; Zhong, Y.; Chen, Y.; Wang, C. Chronic exposure to phenanthrene influences the spermatogenesis of male Sebastiscus marmoratus: U-shaped effects and the reason for them. Environ. Sci. Technol. 2011, 45, 10212-10218. [CrossRef] [PubMed]

46. Holth, T.F.; Nourizadeh-Lillabadi, R.; Blaesbjerg, M.; Grung, M.; Holbech, H.; Petersen, G.I.; Alestrom, P.; Hylland, K. Differential gene expression and biomarkers in zebrafish (Danio rerio) following exposure to produced water components. Aquat. Toxicol. 2008, 90, 277-291. [CrossRef] [PubMed]

47. Meador, J.P.; Sommers, F.C.; Ylitalo, G.M.; Sloan, C.A. Altered growth and related physiological responses in juvenile chinook salmon (Oncorhynchus tshawytscha) from dietary exposure to polycyclic aromatic hydrocarbons (PAHs). Can. J. Fish. Aquat. Sci. 2006, 63, 2364-2376. [CrossRef]

48. Rice, C.A.; Myers, M.S.; Willis, M.L.; French, B.L.; Casillas, E. From sediment bioassay to fish biomarker-Connecting the dots using simple trophic relationships. Mar. Environ. Res. 2000, 50, 527-533. [CrossRef]

49. Kennedy, C.J.; Smyth, K.R. Disruption of the rainbow trout reproductive endocrine axis by the polycyclic aromatic hydrocarbon benzo[a]pyrene. Gen. Comp. Endocrinol. 2015, 219, 102-111. [CrossRef] [PubMed]

50. Rodas-Ortiz, J.P.; Ceja-Moreno, V.; Chan-Cocom, M.E.; Gold-Bouchot, G. Vitellogenin induction and increased plasma 17beta-estradiol concentrations in male nile tilapia, Oreochromis niloticus, exposed to organochlorine pollutants and polycyclic aromatics hydrocarbons. Bull. Environ. Contam. Toxicol. 2008, 81, 543-547. [CrossRef] [PubMed]

51. Tintos, A.; Gesto, M.; Miguez, J.M.; Soengas, J.L. Beta-naphthoflavone and benzo(a)pyrene treatment affect liver intermediary metabolism and plasma cortisol levels in rainbow trout oncorhynchus mykiss. Ecotoxicol. Environ. Saf. 2008, 69, 180-186. [CrossRef] [PubMed]

52. Menuet, A.; Le Page, Y.; Torres, O.; Kern, L.; Kah, O.; Pakdel, F. Analysis of the estrogen regulation of the zebrafish estrogen receptor (ER) reveals distinct effects of eralpha, erbeta1 and erbeta2. J. Mol. Endocrinol. 2004, 32, 975-986. [CrossRef] [PubMed]

53. Abdelrahim, M.; Ariazi, E.; Kim, K.; Khan, S.; Barhoumi, R.; Burghardt, R.; Liu, S.; Hill, D.; Finnell, R.; Wlodarczyk, B.; et al. 3-methylcholanthrene and other aryl hydrocarbon receptor agonists directly activate estrogen receptor alpha. Cancer Res. 2006, 66, 2459-2467. [CrossRef] [PubMed] 
54. Liu, S.; Abdelrahim, M.; Khan, S.; Ariazi, E.; Jordan, V.C.; Safe, S. Aryl hydrocarbon receptor agonists directly activate estrogen receptor alpha in mcf-7 breast cancer cells. Biol. Chem. 2006, 387, 1209-1213. [CrossRef] [PubMed]

55. Hinfray, N.; Nobrega, R.H.; Caulier, M.; Baudiffier, D.; Maillot-Marechal, E.; Chadili, E.; Palluel, O.; Porcher, J.M.; Schulz, R.; Brion, F. Cyp17a1 and cyp19a1 in the zebrafish testis are differentially affected by oestradiol. J. Endocrinol. 2013, 216, 375-388. [CrossRef] [PubMed]

56. Wu, H.; Chen, Y.; Miao, S.; Zhang, C.; Zong, S.; Koide, S.S.; Wang, L. Sperm associated antigen 8 (SPAG8), a novel regulator of activator of crem in testis during spermatogenesis. FEBS Lett. 2010, 584, 2807-2815. [CrossRef] [PubMed]

57. Garcia-Reyero, N.; Villeneuve, D.L.; Kroll, K.J.; Liu, L.; Orlando, E.F.; Watanabe, K.H.; Sepulveda, M.S.; Ankley, G.T.; Denslow, N.D. Expression signatures for a model androgen and antiandrogen in the fathead minnow (Pimephales promelas) ovary. Environ. Sci. Technol. 2009, 43, 2614-2619. [CrossRef] [PubMed]

58. Van den Belt, K.; Wester, P.W.; van der Ven, L.T.; Verheyen, R.; Witters, H. Effects of ethynylestradiol on the reproductive physiology in zebrafish (Danio rerio): Time dependency and reversibility. Environ. Toxicol. Chem. 2002, 21, 767-775. [CrossRef] [PubMed]

59. Weber, L.P.; Hill, R.L., Jr.; Janz, D.M. Developmental estrogenic exposure in zebrafish (Danio rerio): II. Histological evaluation of gametogenesis and organ toxicity. Aquat. Toxicol. 2003, 63, 431-446. [CrossRef]

60. Forsgren, K.L.; Young, G. Stage-specific effects of androgens and estradiol-17beta on the development of late primary and early secondary ovarian follicles of coho salmon (Oncorhynchus kisutch) in vitro. Biol. Reprod. 2012, 87, 64. [CrossRef] [PubMed]

61. Matikainen, T.; Perez, G.I.; Jurisicova, A.; Pru, J.K.; Schlezinger, J.J.; Ryu, H.Y.; Laine, J.; Sakai, T.; Korsmeyer, S.J.; Casper, R.F.; et al. Aromatic hydrocarbon receptor-driven bax gene expression is required for premature ovarian failure caused by biohazardous environmental chemicals. Nat. Genet. 2001, 28, 355-360. [CrossRef] [PubMed]

62. Mattison, D.R. Morphology of oocyte and follicle destruction by polycyclic aromatic hydrocarbons in mice. Toxicol. Appl. Pharmacol. 1980, 53, 249-259. [CrossRef]

63. Johnson, L.L.; Arkoosh, M.R.; Bravo, C.F.; Collier, T.K.; Krahn, M.M.; Meador, J.P.; Myers, M.S.; Reichert, W.L.; Stein, J.E. The effects of polycyclic aromatic hydrocarbons in fish from Puget Sound, Washington. In The Toxicology of Fishes; CRC Press: Boca Raton, FL, USA, 2008; pp. 877-923.

64. Peterson, C.H.; Rice, S.D.; Short, J.W.; Esler, D.; Bodkin, J.L.; Ballachey, B.E.; Irons, D.B. Long-term ecosystem response to the Exxon Valdez oil spill. Science 2003, 302, 2082-2086. [CrossRef] [PubMed]

65. Collier, T.K.; Anulacion, B.F.; Arkoosh, M.R.; Dietrich, J.P.; Incardona, J.P.; Johnson, L.L.; Ylitalo, G.M.; Myers, M.S. Effects on fish of polycyclic aromatic hydrocarbons (PAHs) and naphthenic acid exposures. In Organic Chemical Toxicology of Fishes; Tierney, K.B., Ed.; Elsevier: London, UK, 2014; Volume 33, pp. 195-255.

66. Cailleaud, K.; Forget-Leray, J.; Souissi, S.; Hilde, D.; LeMenach, K.; Budzinski, H. Seasonal variations of hydrophobic organic contaminant concentrations in the water-column of the seine estuary and their transfer to a planktonic species Eurytemora affinis (Calanoida, Copepoda). Part 1: PCBs and PAHs. Chemosphere 2007, 70, 270-280. [CrossRef] [PubMed]

67. Le Goff, J.; Gallois, J.; Pelhuet, L.; Devier, M.H.; Budzinski, H.; Pottier, D.; André, V.; Cachot, J. DNA adduct measurements in zebra mussels, Dreissena polymorpha, Pallas: Potential use for genotoxicant biomonitoring of fresh water ecosystems. Aquat. Toxicol. 2006, 79, 55-64. [CrossRef] [PubMed]

68. Jeanneret, H.; Chantereau, S.; Belliaeff, B.; Ratiskol, G.; Allenou, J.-P.; Piclet, G. Suivi sanitaire et environnemental des conséquences de la marée noire de l'Erika. In Proceedigns of the Colloque SAFERSEAS: Les Leçons Techniques de l'Erika et des Autres Accidents, Brest, France, 11-16 March 2002.

69. Payne, J.R.; Driskell, W.B.; Short, J.W.; Larsen, M.L. Long term monitoring for oil in the Exxon Valdez spill region. Mar. Pollut. Bull. 2008, 56, 2067-2081. [CrossRef] [PubMed]

70. Sol, S.; Johnson, L.; Boyd, D.; Olson, O.; Lomax, D.; Collier, T. Relationships between anthropogenic chemical contaminant exposure and associated changes in reproductive parameters in male english sole (Parophrys vetulus) collected from Hylebos waterway, Puget Sound, Washington. Arch. Environ. Contam. Toxicol. 2008, 55, 627-638. [CrossRef] [PubMed]

71. Johnson, L.L.; Landahl, J.T.; Kubin, L.A.; Horness, B.H.; Myers, M.S.; Collier, T.K.; Stein, J.E. Proceedings of the third international symposium on flatfish ecology, part II: Assessing the effects of anthropogenic stressors on puget sound flatfish populations. J. Sea Res. 1998, 39, 125-137. [CrossRef] 
72. Heintz, R.A. Chronic exposure to polynuclear aromatic hydrocarbons in natal habitats leads to decreased equilibrium size, growth, and stability of pink salmon populations. Integr. Environ. Assess. Manag. 2007, 3, 351-363. [CrossRef] [PubMed]

73. Vignet, C.; Joassard, L.; Lyphout, L.; Guionnet, T.; Goubeau, M.; Le Menach, K.; Brion, F.; Kah, O.; Chung, B.C.; Budzinski, H.; et al. Exposures of zebrafish through diet to three environmentally relevant mixtures of PAHs produce behavioral disruptions in unexposed F1 and F2 descendant. Environ. Sci. Pollut. Res. Int. 2015, 22, 16371-16383. [CrossRef] [PubMed]

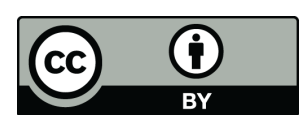

(C) 2016 by the authors; licensee MDPI, Basel, Switzerland. This article is an open access article distributed under the terms and conditions of the Creative Commons Attribution (CC-BY) license (http://creativecommons.org/licenses/by/4.0/). 